\title{
Analisis Sentimen Masyarakat Berdasarkan Opini dari Sosial Media Menggunakan Metode Naive Bayes Classifier (Study Kasus : Universitas Sjakhyakirti)
}

\author{
Paisal $^{1)}$ \\ ${ }^{1)}$ Program Studi Sistem Informasi, Universitas Sjakhyakirti \\ Jl. Sultan Muhammad Mansyur Kb Gede, 32 Ilir, Kec. Ilir Barat II, Kota Palembang \\ Email : paisal@unisti.ac.id ${ }^{1)}$
}

\begin{abstract}
The use of social media today is not only to communicate between friends, but also is needed to make facilities to convey the aspirations of certain people in Indonesia about legal issues relating to government and other issues. One of the aspirations conveyed through social media is a hash that is widely seen by one of the Sjakhyakirti University from the use of social media. Then there arises a lot of sentiment from every community, there are those that give positive sentiments and also negative sentiments that can have a good or bad impact on daily life. days in the community. Some reasons for positive and negative sentiments sourced from this social media, will use social media. From this debate the researchers found a solution where this hashtag can provide good results for the general public or vice versa. In analyzing this, the researcher uses the Nä̈ve Bayes Classifier method which is one of the machine learning methods that uses calculations, the classification of automated hashes can help minimize personal misclassification by obtaining positive or negative sentiment information by using data mining that is carried out by using tools that execute the tools that execute data mining operations that have been determined based on the analysis of models of hidden data on big data thus outlining the discovery of knowledge about Sjakhyakirti University.
\end{abstract}

Keywords : Social Media, Sjakhyakirti, Nä̈ve Bayes Classifie

\begin{abstract}
Abstrak
Pemanfaatan sosial media saat ini tidak hanya untuk berkomunikasi antara teman saja, akan tetapi sering juga dijadikan sebuah sarana untuk menyampaikan suatu aspirasi bagi masyarakat khususnya masyarakat indonesia mengenai masalah hukum ataupun masalah yang berhubungan dengan pemerintahan serta masalah lainnnya. Salah satu aspirasi yang disampaikan melalui sosial media ini adalah sebuah hastag yang banyak dilihat setiap harinya salah satunya mengenai Universitas Sjakhyakirti dari pemanfaaat sosial media ini maka munculah banyak sentimen dari setiap masyarakat, ada yang memberikan sentimen positif dan juga sentimen negatif mengenai tanggapan terhadap hastag tersebut yang dapat berdampak baik atau buruk bagi kehidupan sehari-hari dimasyarakat. Beberapa alasan sentimen positif dan negatif yang bersumber dari sosial media ini, akan memanfaatkan sosial media. Dari permasalahan ini peneliti menghasilkan sebuah solusi dimana hastag tersebut apakah dapat memberikan dampak yang baik bagi masyarakat umumumnya ataupun sebaliknya. Dalam menganalisa ini, peneliti menggunakan metode Nä̈ve Bayes Classifier yang merupakan salah satu metode machine learning yang menggunakan perhitungan probabilitas, pengklasifikasian hastag otomatis ini dapat disesuaikan sehingga meminimalisasi aksi salah pengklasifikasian secara personal dengan memproleh informasi sentimen positif atau negative dengan menggunakan data mining yang dilakukan dengan tool weka yang mengeksekusi operasi data mining yang telah didefinisikan berdasarkan model analisis dari data tersembunyi pada sejumlah data besar sehingga menguraikan penemuan pengetahuan mengenai Universitas Sjakhyakirti.
\end{abstract}

Kata kunci : Sosial Media, Sjakhyakirti, Nä̈ve Bayes Classifie 


\section{Pendahuluan}

Seiring perkembangan teknologi informasi saat ini yang sudah dapat meningkatkan kwalitas kinerja dan memungkinkan berbagai kegiatan dapat dilaksanakan dengan cepat, tepat dan akurat, hingga dapat memberikan kemajuan yang sangat signifikan dalam berbagai bidang seperti bermunculnya berbagai jenis kegiatan yang berbasis teknologi informasi, aplikasi atau perangkat lunak pada beberapa jenis kebutuhan seperti media sosial. Media sosial saat ini telah menjadi tren dalam komunikasi pemasaran. Sosial media adalah sebuah sarana media online, dimana para penggunanya bisa dengan mudah berpartisipasi untuk berbagi, dan menciptakan isi yang meliputi beberapa hal seperti jejaring sosial, blog, forum, wiki, dan dunia virtual. Jejaring sosial, blog dan wiki merupakan bentuk media sosial yang paling umum digunakan oleh masyarakat di seluruh dunia. Sosial media adalah sebuah aplikasi berbasis internet yang dapat membangun di atas dasar ideologi dari sebuah teknologi Web, dan dapat memungkinkan penciptaan dan pertukaran usergenerated content. Pemanfaatan mediasosial ini tidak hanya untuk berkomunikasi antara teman saja, akan tetapi sering juga dijadikan sebuah sarana untuk menyampaikan suatu aspirasi bagi masyarakat khususnya masyarakat indonesia mengenai masalah pemerintahan, ataupun masalah yang berhubungan dengan dunia pendidikan. Salah satu aspirasi yang disampaikan ini seperti beberapa hastag mengenai Universitas Sjakhyakirti yang berhubungan dengan sentimen negatif dan positif. Dalam upaya meningkatkan peminat mahasiswa baru, Universitas Sjakhyakirti perlu mengetahui dan memperoleh opini masyarakat mengenai reputasi dan layanannya sendiri, karena apabila terdapat lebih banyak sentiment negative daripada sentiment positif maka akan membuat reputasi Universitas Sjakhyakirti menjadi buruk di mata masyarakat dan para peminat akan semakin berkurang. Dari permasalahan ini peneliti akan membuat sebuah perangkat lunak yang menganalisa hastag tersebut untuk mendapatkan setimen apa yang terjadi pada masyarakat baik sentimen positif maupun sentimen negatif. Dalam membuat perangkat lunak ini peneliti menggunakan metode Naïve Bayes Classifier yang merupakan salah satu metode machine learning yang menggunakan perhitungan probabilitas (Trinanda, 2019). Konsep dasar yang digunakan dalam metode Nä̈ve bayes adalah Teorema Bayes Classifier, yaitu teorema dalam statistika untuk menghitung peluang yang terjadi, Bayes Optimal Classifier menghitung peluang dari satu kelas atribut dari masing-masing kelompok atribut yang ada, dan menentukan kelas mana yang paling optimal, adapun kelebihan dari penggunaan Naïve Bayes Classifier dalam klasifikasi dokumen dapat ditinjau dari prosesnya yang mengambil aksi berdasarkan data-data yang telah ada sebelumnya (Afshoh, 2017). Oleh karena itu, klasifikasi dalam dokumen dengan metode ini akan dapat dipersonalisasi, maksudnya adalah proses klasifikasi dokumen dapat disesuaikan dengan sifat dan kebutuhan, informasi ini dapat dilihat secara nyata melalui hastagfiltering, dengan cara mengetikkan nama filter hastagnya. Proses klasifikasi dengan menggunakan metode Nä̈ve Bayes classifier akan melakukan proses pengklasifikasian hastag otomatis ini dapat disesuaikan sehingga meminimalisasi aksi salah pengklasifikasian secara personal dengan memperoleh informasi sentimen positif atau negatif. Adapun alasan peneliti membuat perangkat lunak dan memanfaatkan Naïve Bayes classifieryaitu agar dapat dimanfaatkan pihak Universitas Sjakhyakirti dan dijadikan acuan untuk kemajuan dan meningkatkan kinerja dari berbagai pihak yang terkait bagi universitas Sjakhyakirti. Dalam analisis data, media sosial yang digunakan adalah twitter yang merupakan layanan jejaring sosial dan mikroblog daring yang memungkinkan penggunanya untuk mengirim dan membaca pesan berbasis teks dikenal dengan sebutan kicauan (tweet) Wiyadi (2017). Adapun alasan mengapa peneliti memanfaatkan twitter yaitu data tweet dari sosial media ini diizinkan oleh pihak twiiter untuk dijadikan bahan penelitian.

\section{Pembahasan}

\section{A. Pembahasan Teori}

Adapun teori yang akan dibahas dalam penelitian ini adalah :

\section{Analisis Sentimen}

Pang (2008), Analisis sentimen pada suatu kalimat menggambarkan bagian pertimbangan penilaian terhadap entitas atau kejadian tertentu. Analisis sentimen juga dapat dikatakan sebagai opinion mining. Analisis sentimen dapat digunakan dalam berbagai kemungkian domain, dari produk konsumen, jasa kesehatan, jasa keuangan, peristiwa sosial dan politik pada pemilu. Kecendrungan penelitian tentang analisis sentimen berfokus pada pendapat yang menyatakan atau menyiratkan suatu sentimen positif atau negatif. Pendapat mewakili hampir semua aktivitas manusia, karena pendapat dapat mempengaruhi terhadap perilaku seseorang. Setiap kali kita perlu membuat keputusan, kita ingin tahu pendapat orang lain. Dalam dunia nyata, bisnis dan organisasi selalu ingin melihat opini publik tentang suatu produk atau jasa (Liu, 2012).

\section{Media Sosial}

Menurut Evans (2008), media sosial selalu berubah dariwaktu ke waktu sehingga memungkinkan seseorang dapatmenjadi kedua pihak, yaitu penerima informasi dan juga penyebarinformasi. Secara garis besar media sosial bisa dikatakan sebagai sebuah media online, di mana para penggunanya (user) melalui aplikasi berbasis internet dapat berbagi, berpartispasi, dan menciptakan konten berupa blog, wiki, forum, jejaring sosial, dan ruang dunia virtual yang disokong oleh teknologi multimedia menjadi satu kesatuan yang sulit dipisahkan serta mendorong pada hal-hal baru. Saat ini media sosial yang paling banyak digunakan dan bertumbuh pesat yaitu berupa jejaring sosial, blog dan wiki. Merebaknya situs media sosial yang muncul menguntungkan banyak 
orang dari berbagai belahan dunia untuk berinteraksi dengan mudah dan dengan biaya yang murah ketimbang memakai telepon. Dampak positif yang lain dari adanya situs jejaring sosial adalah percepatan penyebaran informasi. Akan tetapi ada pula dampak negatif dari media sosial, yakni berkurangnya interaksi interpersonal secara langsung atau tatap muka, munculnya kecanduan yang melebihi dosis, serta persoalan etika dan hukum karena kontennya yang melanggar moral, privasi serta aturan.

Sebagaimana yang sudah dijelaskan di atas tentang pengertian media sosial, yakni sebuah media online artinya pengguna media online tersebut dapat berkomunikasi tanpa harus tatap muka. Awal munculnya media sosial pada abad 70-an, tepatnya tahun 1978, saat sistem papan buletin atau bulletin board system (BBS) ditemukan oleh Ward Christensen dan Randy Suess yang merupakan pecinta dunia komputer. Sistem papan ini memungkinkan pengguna (user) untuk bisa berhubungan dengan orang lain memakai surat elektronik atau mengunggah dan mengunduh melalui perangkat lunak yang tersedia saat itu. Ini merupakan awal sebuah komunitas virtual dalam lingkup terbatas.

Dengan seiring waktu berjalan munculah berbagai media sosial dengan seabrek keunggulan, keunikan, karakteristik, dan segmentasi yang beragam. Kemunculan sejumlah situs jejaring sosial itu pada intinya bermula dari adanya inisiatif untuk menghubungkan orang-orang dari berbagai latar belakang yang ada di seluruh belahan bumi. Dalam perkembangan lebih lanjut, media sosial kini menjadi sarana aktifitas yang masuk kategori digital marketing, karena banyak dijejali kemasan dan muatan pemasaran Salah satu mendasar yang ada pada situs-situs media sosial tersebut adalah fungsi dan layanan jejaring sosial.

Layanan jejaring sosial memberikan jasa koneksi aktifitas melalui situs, platform dan dan saran yang berfungsi memfasilitasi pembentukan jaringan atau hubungan sosial di antara beragam orang yang mempunyai ketertarikan, minat (interest), kegiatan, latar belakang, maksud, kepentingan, tujuan, atau korelasi dunia nyata yang sama. Dari uraian sejarah media sosial diatas telah memunculkan berbagai karakteristik jenis media sosial. Maka dari itu pada era ini banyak macammacam bentuk media sosial yang tercipta dan memiliki perbedaan dan karakteristik sendiri-sendiri.

Menurut penelitian Overdrive, suatu lembaga riset pemasaran, jenis aplikasi media sosial saat ini sedikitnya telah mencapai 240 aplikasi yang menawarkan ratusan cara berinteraksi. Dari penelitian tersebut memperlihatkan keunikan interaksi aplikasi media sosial sangat beragam. Dalam bentuk yang simpel, media sosial adalah bentuk lintas komunikasi lewat penyebaran konten. Materi atau konten itu dapat berupa suatu percakapan diskusi, video, opini, foto dan sebagainya. Dalam hal inilah, lembaga pemerintahan harus turut berperan, bergabung dan secara maksimal dapat memanfaatkan fasilitas ini.
3. Twitter

Twitter adalah situs microblogging yang dioperasikan oleh Twitter, Inc. Disebut micro blogging karena situs ini memungkinkan penggunanya mengirim dan membaca pesan seperti blog pada umumnya. Pesan tersebut dinamakan tweets, yaitu teks tulisan sebanyak 140 karakter yang ditampilkan pada halaman profil pengguna. Perkembangan dunia teknologi semakin memudahkan para pengguna Twitter yang kian hari kian bertambah. Melalui aplikasi eksternal yang kompatibel seperti telepon seluler atau dengan SMS, penggunanya dapat mengirim dan menerima tweets langsung dari situs Twitter. Dengan kemudahan seperti ini, Twitter telah mendapatkan tempat di seluruh dunia dengan semakin bertambahnya jumlah users. Twitter dibentuk dan diluncurkan pada 2006 oleh Jack Dorsey. Pendirian Twitter, Inc. dibiayai oleh Obvious LLC. Markasnya terletak di San Bruno, California. Kemudian, server dan kantor Twitter yang lain tersebar di San Antonio, Texas dan Boston, Massachusetts. Twitter menjadi popular pada tahun 2007 pada festival South by Southwest. Selama acara tersebut berlangsung, pengguna Twitter meningkat dari 20.000 tweets per hari menjadi 60.000 tweets. Pada September 2010, Twitter mengganti logo dan membuat desain.

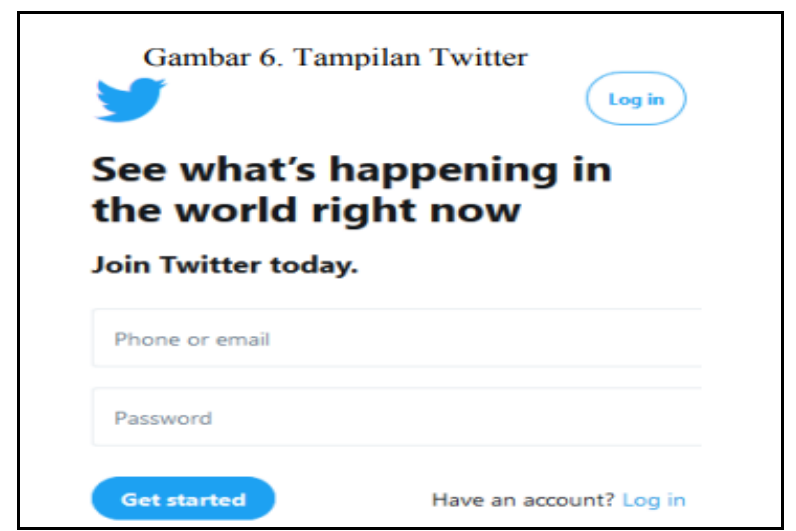

Gambar 1. Tampilan Twitter

\section{Metode Naive Bayes}

Menurut Bustami (2013), Naive Bayes adalah sebuah cara untuk pengklasifikasian probabilistik yang sederhana untuk menghitung sekumpulan probabilitas dengan menjumlahkan frekuensi dan kombinasi nilai dari dataset yang diberikan. Algoritma yang mengunakan teorema Bayes dan mengasumsikan semua atribut independen atau yang tidak saling ketergantungan untuk diberikan pada nilai variabel kelas. Definisi lain mengatakan Naive Bayes merupakan pengklasifikasian dengan metode probabilitas dan statistik yang dikemukan oleh ilmuwan Inggris Thomas Bayes, yaitu memprediksi peluang di masa depan berdasarkan pengalaman di masa sebelumnya. Naive Bayes didasarkan dari asumsi penyederhanaan sebuah nilai atribut secara kondisional yang saling bebas jika diberikan nilai output. Dengan kata lain, diberikan nilai output, probabilitas mengamati secara bersama adalah produk dari probabilitas individu (Ridwan, Suyono dan 
Sarosa, 2013). Penggunaan metode Naive Bayes memiliki beberapa keuntungan yaitu metode ini hanya membutuhkan jumlah data pelatihan (Training Data) yang kecil dalam menentukan estimasi paremeter yang diperlukan dalam proses pengklasifikasian. Naive Bayes sering bekerja lebih baik dalam kebanyakan situasi baik dunia nyata yang kompleks dari pada yang diharapkan. Dapat dilihat pada rumus 2.1 dibawah ini.

$$
P(H \mid X)=\frac{P(X \mid H) \cdot P(H)}{P(X)}
$$

Sumber : (Bustami, 2013)

Di mana :

\begin{tabular}{|c|c|}
\hline$X$ & Data dengan class yang belum diketahui \\
\hline $\mathrm{H}$ & $\begin{array}{l}\text { Hipotesis data merupakan suatu class } \\
\text { spesifik }\end{array}$ \\
\hline $\mathrm{P}(\mathrm{H} \mid \mathrm{X})$ & $\begin{array}{l}\text { Nilai Probabilitas hipotesis dari } \mathrm{H} \text { berdasar } \\
\text { dari kondisi X (posteriori probabilitas) }\end{array}$ \\
\hline $\mathrm{P}(\mathrm{H})$ & $\begin{array}{l}\text { Nilai Probabilitas hipotesis } \mathrm{H} \text { (prior } \\
\text { probabilitas) }\end{array}$ \\
\hline $\mathrm{P}(\mathrm{X} \mid \mathrm{H})$ & $\begin{array}{l}\text { Nilai Probabilitas } \mathrm{X} \text { berdasarkan kondis } \\
\text { pada hipotesis } \mathrm{H}\end{array}$ \\
\hline$(\mathrm{X})$ & Probabilitas X \\
\hline
\end{tabular}

5. Datamining

Data mining (penambangan data) adalah suatu proses untuk menemukan suatu pengetahuan atau informasi yang berguna dari data berskala besar. Sering juga disebut sebagai bagian dari proses KDD (Knowledge Discovery in Databases) (Santosa, 2007).

Data mining terbagi menjadi beberapa kelompok yang berdasarkan tugas dilakukan, yaitu :

1. Deskripsi

Terkadang peneliti dan analis secara sederhana ingin mencoba mencari cara untuk menggambarkan pola dan kecendrungan yang terdapat dalam data. Deskripsi dari pola kecendrungan ini, sering memberikan kemungkinan penjelasan untuk suatu pola atau kecendrungan.

2. Estimasi

Estimasi hampir sama dengan proses klasifikasi, kecuali variabel dari target estimasi lebih ke arah numerik dari pada arah kategori. Model dibangun dengan record lengkap menyediakan nilai dari variabel target sebagai nilai prediksi. Selanjutnya, peninjauan berikutnya yaitu estimasi nilai dari variabel target dibuat berdasarkan nilai variabel prediksi.

3. Prediksi

Prediksi hampir sama dengan proses klasifikasi dan proses estimasi, kecuali bahwa dalam prediksi nilai dari hasil akan ada di masa mendatang. Beberapa metode serta teknik yang digunakan dalam klasifikasi dan estimasi dapat pula digunakan (untuk keadaan yang tepat) untuk prediksi.

4. Klasifikasi

Dalam klasifikasi, terdapat target variabel kategori. Sebagai contoh, penggolongan pendapatan dapat dipisahkan dalam tiga kategori, yaitu pendapatan tinggi, pendapatan sedang, dan pendapatan rendah.

5. Pengklusteran
Pengklusteran merupakan pengelompokan beberapa record serta pengamatan atau memperhatikan dan membentuk kelas objek-objek yang memiliki kemiripan. Kluster adalah sekumpulan beberapa record yang memiliki beberapa kemiripan yang satu dengan yang lainnya dan memiliki ketidakmiripan dengan recordrecord dalam kluster lain. Pengklusteran sangat berbeda dengan klasifikasi yaitu dimana pengklusteran tidak adanya variabel target dalam pengklusteran. Pengklusteran tidak mencoba untuk melakukan klasifikasi serta mengestimasi atau memprediksi nilai dari variabel target. Dalam algoritma pengklusteran ini akan melakukan pembagian terhadap keseluruhan data menjadi kelompok-kelompok yang memiliki kemiripan record dalam satu kelompok yang akan bernilai maksimal, sedangkan kemiripan dengan record dalam kelompok lain akan bernilai minimal.

6. Asosiasi

Tugas asosiasi dalam sebuah data mining adalah menemukan atribut yang muncul dalam satu waktu. Dalam dunia bisnis lebih umum disebut sebagai analisis keranjang belanja (market basket analysis). (Larose, 2005).

Adapun arsitektur utama sistem data mining, pada umumnya terdiri dari beberapa komponen sebagai berikut :

a. Database, data warehouse, atau media penyimpanan informasi, terdiri dari satu atau beberapa database, data warehouse, atau data dalam bentuk lain. Pembersihan data dan integrasi data dilakukan terhadap data tersebut.

b. Database, data warehose, bertanggung jawab terhadap pencarian data yang relevan sesuai dengan yang diinginkan pengguna atau $u$ ser.

c. Basis pengetahuan (Knowledge Base), merupakan basis pengetahuan yang digunakan sebagai panduan dalam pencarian pola.

d. Mining Engine, merupakan bagaian penting sebuah sistem yang terdiri dari beberapa kumpulan modulmodul fungsi yang digunakan dalam proses), klasifikasi (clasiffication), karakteristik (characterization) dan analisis kluster (cluster analysis). Dan merupakan bagian dari software yang menjalankan program berdasarkan algoritma yang ada.

e. Evaluasi pola (pattern evaluation), komponen ini pada umumnya berinteraksi dengan modul-modul data mining. Bagian dari software yang berfungsi untuk menemukan pattern atau pola yang terdapat dalam database yang dapat diolah sehingga nantinya proses data mining dapat menemukan knowledge yang sesuai.

f. Antar muka (Graphical user interface), merupakan modul komunikasi antara pengguna atau user dengan sistem yang memungkinkan pengguna berinteraksi dengan sistem untuk menentukan proses data mining itu sendiri. 


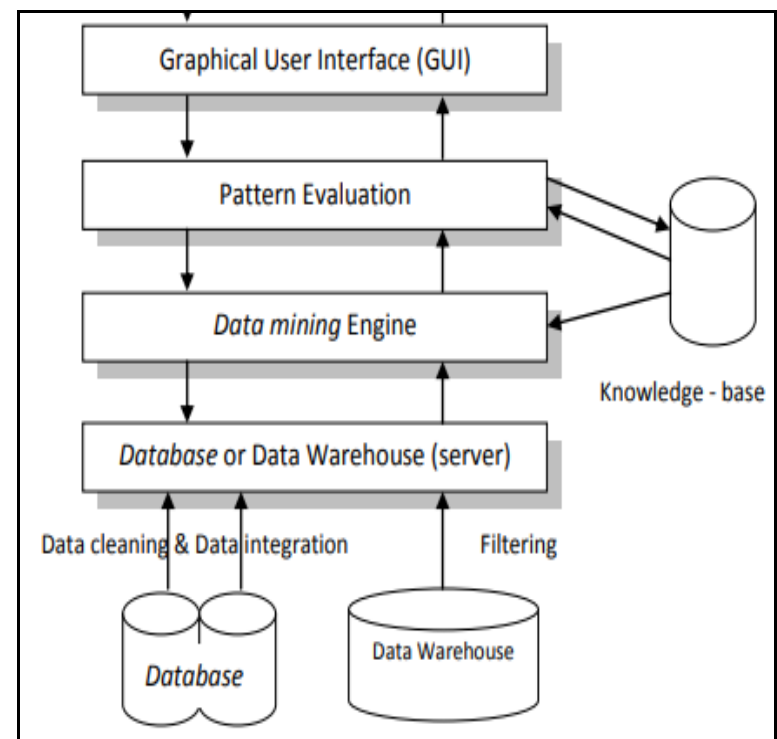

Gambar 2. Arsitektur Data mining

\section{Weka}

Widiarsono (2005), weka adalah suatu software yang dapat membantu dalam memecahkan berbagai masalah matematis yang terdapat dalam kehidupan sehari-hari yang lebih tepatnya dalam bidang teknis. Kita bisa memanfaatkan kemampuan weka dalam menemukan solusi dari berbagai masalah numeric secara tepat dan cepat, yang dimulai dari hal yang paling dasar, misalkan sistem 2 persamaan dengan 2 variabel: $x-2 y=3212 x+$ $5 y=12$ hingga yang kompleks, seperti mencari akarakar polinomial, interpolasi darisejumlah data, perhitungan dengan matriks, pengolahan sinyal, dan metodanumerik. Weka merupakan kepanjangan dari Matrix Laboratory. Sesuai dengannamanya, struktur data yang terdapat dalam Weka menggunakan matriks atauarray berdimensi dua (double). Oleh karenanya penguasaan teori matriks mutlakdiperlukan bagi pengguna pemula Weka agar mudah dalam mempelajari danmemahami operasi-operasi yang ada di Weka

\section{B. Pembahasan Hasil}

Adapun hasil yang akan dibahas dalam penelitian ini adalah :

1. Proses Crawling Aplikasi Tags V6.1.9

Setelah melakukan analisa terhadap perancangan data mining untuk Analisis Sentimen Masyarakat Terhadap Universitas sjakhyakirti Berdasarkan Opini Dari Twitter Menggunakan Metode Naive Bayes Classifier, analisa ini berakhir dengan melakukan proses datamining yang sesungguhnya, maka hasil yang dicapai oleh penulis adalah untuk memprediksi Analisis Sentimen Masyarakat Terhadap Universitas Sjkahkyakirti Berdasarkan Opini Dari Twitter Menggunakan Metode Naive Bayes Classifier dalam memudahkan proses datamining ini peneliti menggunakan aplikasi weka dari tabel data yang menampung data sentimen Universitas Sjkahkyakirti yang kemudian menghasilkan informasi data sentimen positif, netral dan negatif. Adapun proses pengambilan data sebagai berikut.

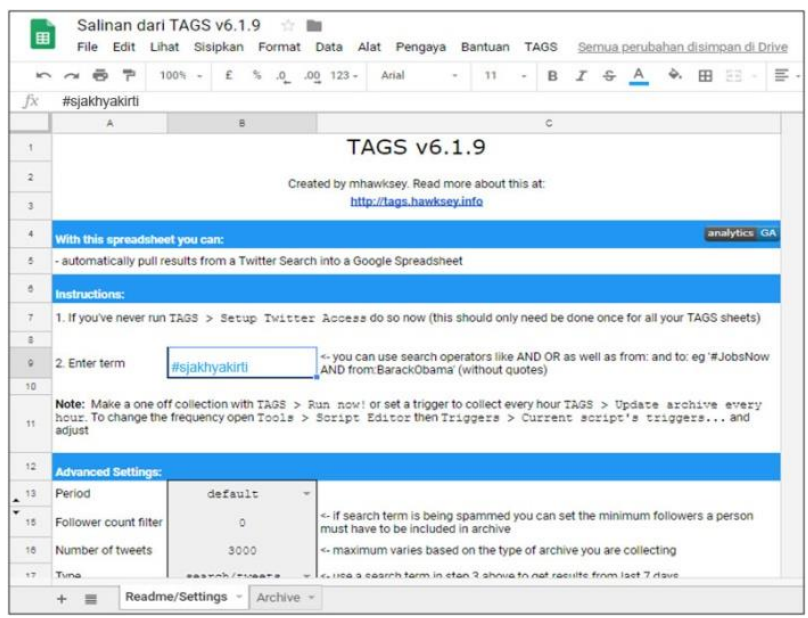

Gambar 3. Aplikasi Tags V6.1.9

\section{Preprocess}

Explorer data akan dilakukan dengan menggunakan aplikasi weka. Proses ini akan digunakan untuk memilih file yang diolah melalui file csv.

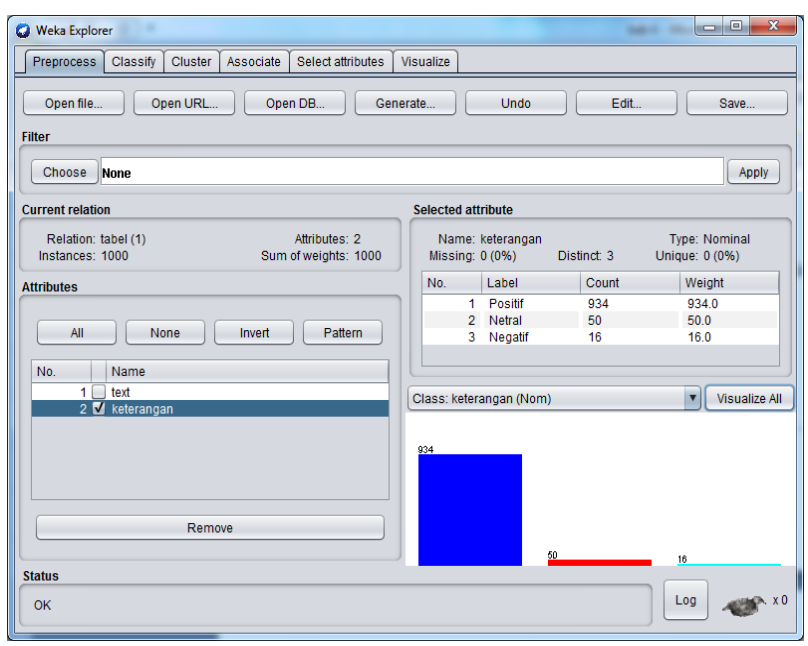

Gambar 4. Proses Explorer

\section{Classify}

Classify data akan dilakukan dengan menggunakan aplikasi weka. Proses ini digunakan untuk membuat class mengenai data Analisis Sentimen Masyarakat Terhadap Universitas Sjakhyakirti Berdasarkan Opini Dari Twitter Menggunakan Metode Naive Bayes Classifier Netral, Negatif dan Positif data akan dilakukan dengan menggunakan aplikasi weka. Proses ini digunakan untuk membuat class mengenai data sentimen berdasarkan Analisis Sentimen Masyarakat Terhadap Universitas Sjakhyakirti berdasarkan opini dari Twitter Menggunakan Metode Naive Bayes Classifier. 


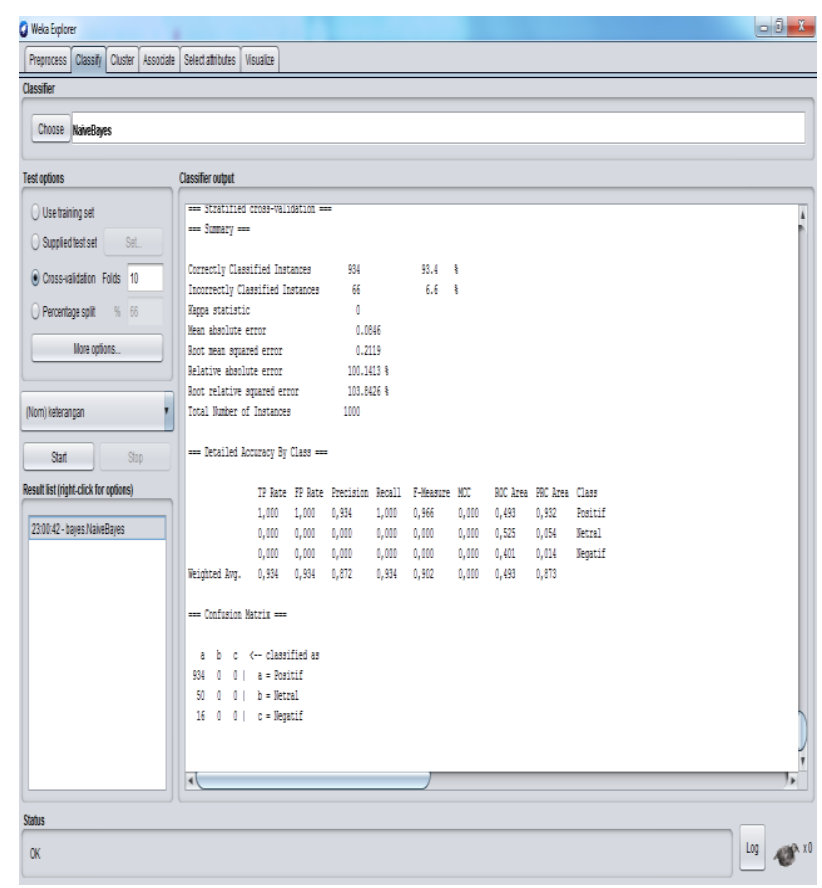

Gambar 5. Proses Jumlah Sentimen

\section{Kesimpulan}

Berdasarkan hasil penelitian penulis yang dilakukan serta pembahasan yang dilakukan oleh penulis maka dapat diambil kesimpulan bahwa :

1. Dalam penelitian ini hanya sebatas mengetahui teknik apasaja yang dilakukan dalam proses text mining dengan memanfaatkan data sosial media dari twitter.

2. Sesuai dengan tujuan dari penelitian ini yaitu Analisis Sentimen Masyarakat Terhadap Universitas Sjakhyakirti Berdasarkan Opini Dari Twitter Menggunakan Metode Naive Bayes Classifier yang dapat digunakan untuk melakukan evaluasi yang dapat berpengaruh besar terhadap kemajuan universitas jakhyakirti.

3. Proses evaluasi diharapkan dapat memudahkan mendapatkan informasi mengenai data Sentimen Masyarakat Terhadap Universitas Sjakhyakirti Berdasarkan Opini dari Twitter yang paling banyak berdasarkan kategori yaitu netral, negatif, positif.

\section{DaftarPustaka}

Afshoh, F. 2017. Analisa Sentimen Menggunakan Nä̈ve Bayes Melihat Persepsi Masyarakat Terhadap Kenaikan Harga Rokok Media Sosial Twitter. Fakultas Komunikasi dan Informatika Universitas Muhammadiyah Surakarta.

Bustami. 2013. Penerapan Algoritma Nä̈ve Bayes untuk Mengklasifikasi Data. Nasabah Asuransi. Aceh

Evans, J.R. and Lindsay W.M. 2008. The Management and Control of Quality(7th Edition). Ohio: Thomson South-Western.

Larose D, T., 2005, Discovering knowledge in data : an introduction todata mining, Jhon Wiley \& Sons Inc
Liu B. 2012. Sentiment Analysis and Opinion Mining. Morgan \& Claypool Publisher

Pang, Bo., dan Lee, Lillian. 2008. Opinion Mining and Sentiment Analysis. Computer Science Department

Santosa, Budi. 2007. Data Mining Teknik Pemanfaatan Data untuk KeperluanBisnis. Yogyakarta : Graha Ilmu.

Trinanda, Reggy Pasya. 2019. Teknik Data Mining Metode Bayes Classifier Optimalisasi Pencarian Pada Aplikasi Perpustakaan.Universitas PasundanBandung.

Widiarsono, Teguh 2005. Tutorial Praktis Belajar Matlab. pdf, Jakarta

Wiyadi, Yudi Permana. 2017. Pengaruh Tokoh Ahok Pada Media Sosial MenjadiTrending Topic Menggunakan Metode Classification. Fakultas Teknik Universitas Muhammadiyah Jakarta. 